\begin{tabular}{|} 
Ambiente \& Água - An Interdisciplinary Journal of Applied Science \\
ISSN 1980-993X - doi:10.4136/1980-993X \\
www.ambi-agua.net \\
E-mail: ambi.agua@gmail.com
\end{tabular}

\title{
Impacts of urban life on water quality and fish larvae communities in two creeks of the Brazilian Amazon
}

\author{
doi:10.4136/ambi-agua.1763
}

Received: 26 Sep. 2015; Accepted: 25 Nov. 2015

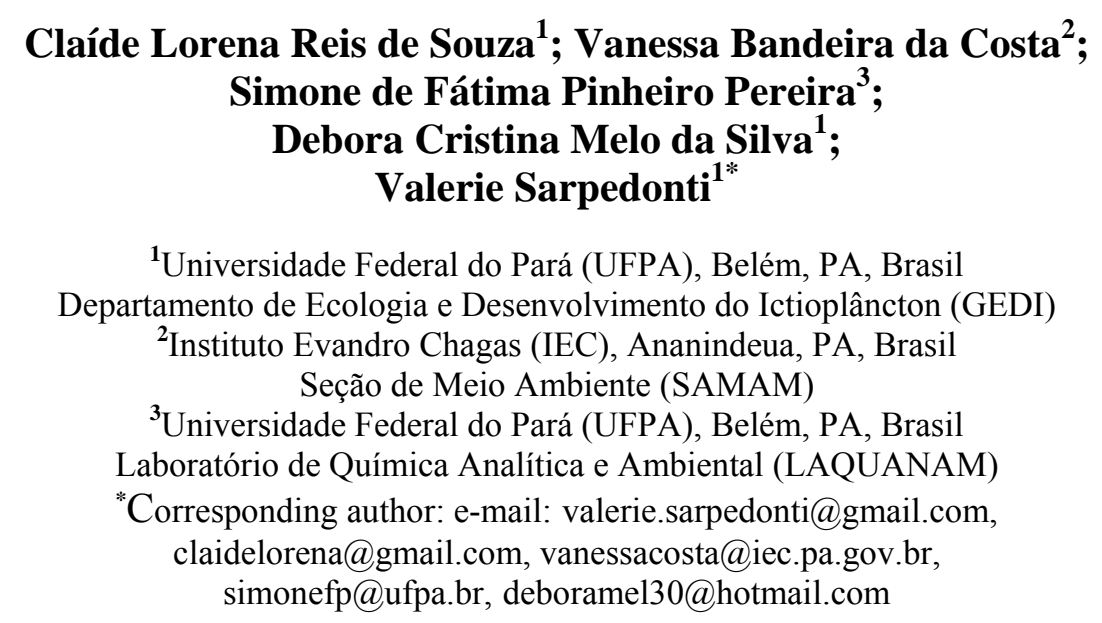

ABSTRACT

This study investigated the impact of anthropogenic activities in Belém City, Brazilian Amazon, by comparing water quality and fish larvae communities in two creeks that flow into the Guamá River. One creek crossed a poor and crowded suburb of Belém while the other was located in an island section that was declared an Environmental Protected Area in 1997. Two sampling points were set in each creek and monitored over eight hours once every three months over a one-year period. Strong variations of water quality were registered all year long and at all tides in Belém's mainland creek, along with, among other things, a very high number of thermotolerant coliforms. Few larvae were found. The water was considered unsuitable for human use and activities as well as for aquatic life. The island creek presented early signs of bacterial and nutrient contaminations during the rainy season, probably partly related to non-point source pollution. In both creeks, larvae communities were almost exclusively composed of clupeiforms. All larval development stages were encountered. Higher densities and proportion of newly hatched larvae were registered during the dry season and associated with the presence of nitrate. The results of the study show that adequate sewage and drainage systems must be developed in the city and suggest that it would be useful to conduct an integrated ambient monitoring study in Combú Creek.

Keywords: environmental protected area, pollution, urbanization.

\section{Impactos da vida urbana sobre a qualidade da água e comunidade de larvas de peixes em dois igarapés da Amazônia brasileira}

\section{RESUMO}

Este estudo teve como objetivo investigar o impacto das atividades antropogênicas da 
cidade de Belém pela comparação da qualidade da água e das comunidades de larvas de peixes em dois igarapés que desembocam no rio Guamá. Um dos igarapés atravessa um subúrbio pobre e populoso de Belém, enquanto o outro é localizado em uma ilha de Belém, declarada Área de Proteção Ambiental desde 1997. Dois pontos de coletas foram definidos em cada igarapé e monitorados durante oito horas, a cada três meses e durante um ano. $\mathrm{O}$ igarapé em região urbana apresentou fortes alterações na qualidade da água, durante o ano todo e em todas as marés, e isto deve se essencialmente a presença de um elevado número de coliformes termotolerantes. Poucas larvas foram encontradas. A água foi considerada imprópria para uso e atividades humanas, assim como para a vida aquática. O igarapé da ilha apresentou primeiros sinais de contaminação por nutrientes e bactéria durante o período chuvoso, parcialmente decorrente de fontes de poluição difusa. Em ambos os córregos, as comunidades larvais foram quase exclusivamente compostas de clupeiformes. Todos os estágios de desenvolvimento larval foram encontrados. Densidades e proporções mais elevadas de larvas recém eclodidas foram registradas durante a estação seca e associadas à presença de nitrato. Resultados apontam a necessidade de desenvolver um sistema de drenagem urbano para esgoto e água pluvial na maior brevidade, e recomenda um estudo de monitoramento integrado do igarapé na Área de Proteção Ambiental.

Palavras-chave: Área de proteção ambiental, poluição, urbanização.

\section{INTRODUCTION}

Water is one of the earth's most precious elements, upon which all life forms on the planet rely. Unfortunately, both the quality and quantity of water are currently threatened by human activities, lack of awareness and irresponsible behavior. While first-world countries may abuse water resources to support their lifestyles, developing countries struggle to provide basic needs to their citizenry (WWF, 2006). There are a variety of issues that make it difficult to bring the water crisis under control, such as the economic cost, politics, culture, education and lack of scientific knowledge. Over the past few decades megalopoli, such as Mexico City or Mumbai, have experienced a rapid and uncontrolled population increase that has led to severe water pollution in areas completely devoid of sanitation or drainage systems (SosaRodriguez, 2012).

Brazil, world's fifth-largest country both geographically and by population, also faces daily challenges to promote the 'right to the city' (Friendly, 2013). A study conducted in 2012 by the SNIS (Brazilian National Sanitation Information System ) of all 27 Brazilian state capitals indicated that the worst sanitation conditions are in Belém City, the capital of Pará State. Belém City is part of the Amazonian territory, and includes not only a continental urban center where approximately $98 \%$ of its population lives (1.4 million inhabitants in 2012), but also 39 poorly developed islands which represent 64\% of Belem's surface. In 1997, one of these islands, Combú Island, was declared an "Environmental Protected Area" (State law $6,083)$. The island is separated from Belém's mainland by the Guamá River, which also acts as a receptacle for contaminated waters deposited by the numerous creeks that flow through the city. Both the filthy living conditions in some suburbs, and their proximity to the protected island, suggest the need for quick implementation of water quality monitoring surveys in order to assess the actual levels of contamination in both impacted and supposedly nonimpacted areas, as a first and obligatory step to environmental risk management studies (Peptenatu et al., 2011).

This study compared water quality and fish larvae communities in two creeks, one that flows through a poor human settlement on Belém's mainland and another that passes through part of the Environmental Protected Area of Combú Island. Seasons, tides and larval 
development stages were considered. The results of the study will support follow-up studies of water pollution spreading from the city center towards the islands as well as of possible alterations of icthyoplankton communities. It is also hoped that, based on actual water quality data of the mainland creeks, the government may act to implement proper sanitation conditions and to protect aquatic resources that not only provide a source of food and livelihood for the local inhabitants, but also represent the diversity and richness of the Amazonian region.

\section{MATERIALS AND METHODS}

\subsection{Study area and Sampling}

The city of Belém, capital of Pará State, is located in the oligohaline zone of the Amazon region. It is surrounded by the Guamá River on its southern side, which carries large amount of suspended material from the Amazon and Tocantins river systems. Guamá River waters flow into Guajará Bay, on the eastern side of the city, considered the most exposed to human activities. Guajará Bay is then connected to Marajó Bay from which the waters flow into the ocean.

The two creeks selected for this study are located on opposite banks of the Guamá River: the Combú Creek, about $5 \mathrm{~km}$ long, crosses Combú Island, a preserved environment with few inhabitants that depend essentially on natural resources for their daily subsistence; and the Tucundubu Creek, about $4 \mathrm{~km}$ long, that passes through numerous human settlements which lack proper sanitation facilities. Two collection points were defined in each creek: downstream points $\mathrm{C} 1$ and $\mathrm{T} 1{ }^{\circ}\left(1^{\circ} 29^{\prime} 24.13^{\prime \prime S} / 48^{\circ} 27^{\prime} 41.93^{\prime \prime} \mathrm{W}\right.$ and $1^{\circ} 28^{\prime} 35.74^{\prime \prime} \mathrm{S} /$ $48^{\circ} 27^{\prime} 13.34^{\prime \prime} \mathrm{W}$, respectively) and $1 \mathrm{~km}$ inland points $\mathrm{C} 2$ and $\mathrm{T} 2$ (1 ${ }^{\circ} 29^{\prime} 53.16^{\prime \prime S}$ / $48^{\circ} 27^{\prime} 40.26^{\prime \prime} \mathrm{W}$ and $1^{\circ} 28^{\prime} 06.02^{\prime \prime} \mathrm{S} / 48^{\circ} 27^{\prime} 11.71^{\prime \prime} \mathrm{W}$, respectively) (Figure 1). Samplings were collected once per season in 2011 and 2012. Seasons in North Brazil are defined according to rainfall intensity: wet season (January to March), wet/dry transition season (April to June), dry season (July to September) and dry/wet transition season (October to December). Field trips occurred on two consecutive days (one day per creek) at the quarter moon; sampling was done at point 1 before sampling at point 2 and then returning to point 1 one hour later to conduct one more sampling set. Two pseudo-replicates were taken per sampling point. The overall survey lasted eight hours in order to include both ebb and flood tides, totaling about 32 samples day ${ }^{-1}$ creek $^{-1}$ (two pseudo-replicates per points, with two points per creek sampled eight times a day).

Fish larvae collection was done using a conical plankton net of $50 \mathrm{~cm}$ diameter, $330 \mu \mathrm{m}$ in mesh size, pulled by a small motorized vessel for 3 mins (license collection 18.152-1). Water volumes filtered at each trawl were assessed by a flowmeter placed at the net mouth. All samples were fixed in 4\% formaldehyde solution neutralized with sodium tetraborate.

In order to evaluate water parameters, sub-surface water was collected before each trawl using a five-liter 'Van Dorn' bottle. Chemical oxygen demand $\left(\mathrm{COD}_{5}-\mathrm{mg} \mathrm{L}^{-1}\right)$, biological oxygen demand (BOD - mg L $\mathrm{L}^{-1}$ ), dissolved oxygen $\left(\mathrm{DO}-\mathrm{mg} \mathrm{L}^{-1}\right)$, conductivity $(\mathrm{Cnd}-\mu \mathrm{S}$ $\mathrm{cm}^{-1}$ ) and total dissolved solids (TDS - $\mathrm{mg} \mathrm{L}^{-1}$ ) were assessed using a YSI 6600 multiparameters gauge; nitrate $\left(\mathrm{NO}_{3}^{-}-\mathrm{mg} \mathrm{L}^{-1}\right)$, ammonium $\left(\mathrm{NH}_{4}^{+}-\mathrm{mg} \mathrm{L}^{-1}\right)$ and phosphorus $\left(\mathrm{PO}_{4}{ }^{3-}-\mathrm{mg} \mathrm{L}^{-1}\right)$ concentrations were determined using an Ion Chomatography System (ICS DUAL 2000 DIONEX, USA); thermotolerant fecal coliforms (CTr most probable number MPN $100 \mathrm{ml}^{-1}$ ) were counted using a Collilert $-18^{\circledR} /$ Quanti-Tray ${ }^{\circledR} / 2000$ chromogenic substrate method from IDEXX Laboratories, Inc. and following the Standard Methods for the Examination of Water and Wastewater. 
a)

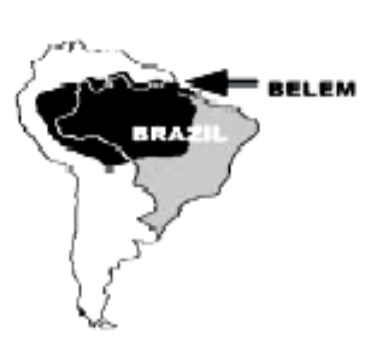

c)

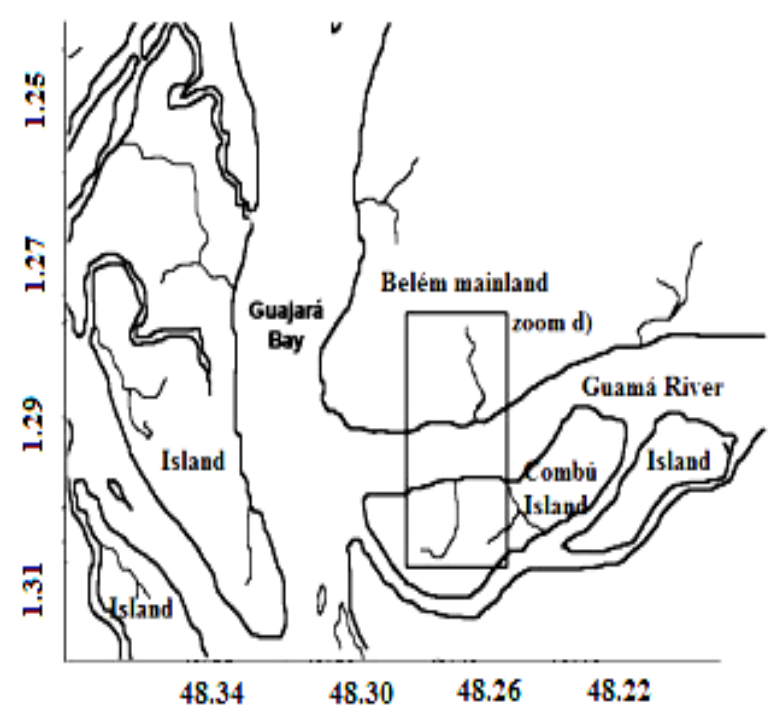

b)

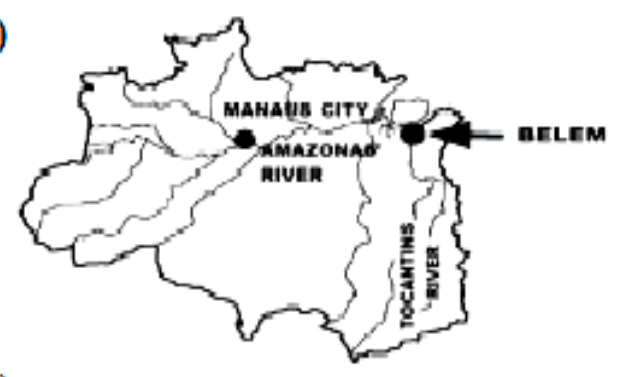

d)

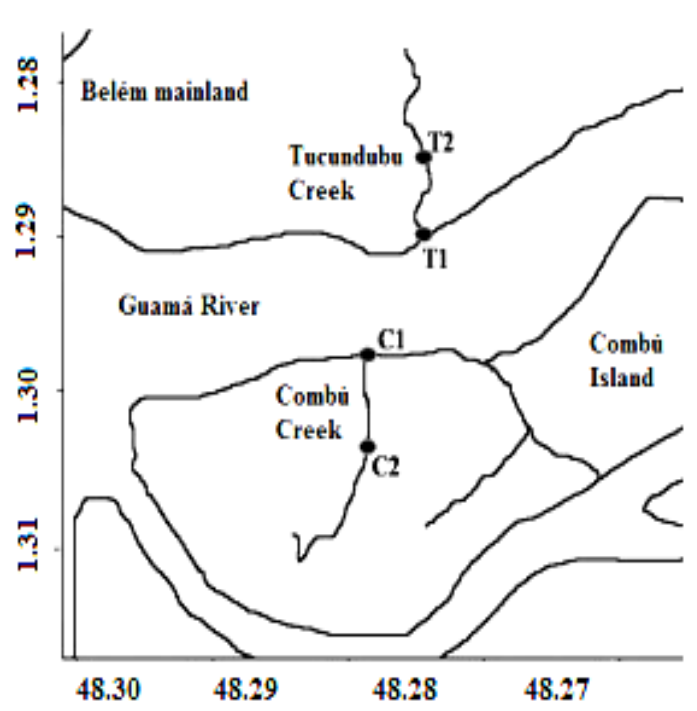

Figure 1. Study area a) South America, with the Amazonian territory (in black) and Brazilian borderline; b) Brazilian amazon and location of Belém City; c) Belém City including mainland area and some islands; and d) zoom on the sampling sites C1 and C2 in Combú Creek and T1 and T2 in Tucundubu Creek.

Larvae were separated from debris and other organisms using a stereomicroscope (Motic/Motion SMZ 134) and transferred to a 70\% alcohol solution. Subsequently, individuals were identified at the family level based, among other things, on fin characteristics, number of myomeres, shape, size of the digestive tract and pigment distribution. Fish larvae collections and literature were also consulted (Nakatani et al., 2001). Four larval developmental stages were separated based on the flexion of the notochord (pre-flexion, flexion and post-flexion stages) and presence / absence of the yolk-sac (yolk-sac stage).

\subsection{Data analysis}

Densities (number of larvae $100 \mathrm{~m}^{-3}$ ) were calculated, separated by seasons, sampling sites, tides, taxa and developmental stages. Data were $\log (x+1)$ transformed to increase the normality; similarity between densities was tested through analysis of variance (Hammer, 2001). Kolmogorov-Smirnov and Tukey tests were used to compare fish larvae mean densities and water parameters, respectively between ebb and flood tides, seasons and upstream/downstream sites. A Principal Component Analysis (PCA) was performed to relate water parameters with tides and seasons. The BIOENV routine based on Spearman correlation analysis was performed to assess which environmental variables were associated with fish larvae communities during the period of study. 


\section{RESULTS AND DISCUSSION}

\subsection{Water quality}

In developing countries, creeks or open drains act as the main collectors for urban pollution generated by industrial and domestic activities (Srivastava et al., 2011). Although Belém is not considered as a big industrial center, the lack of sanitation systems throughout the city renders the aquatic ecosystem vulnerable to heavy loads of organic material. This study showed that Tucundubu Creek is a good example of this. The creek presented both temporal and spatial changes $(\mathrm{p}<0.05)$ in water quality. Higher concentrations of thermotolerant coliforms, COD, TDS and conductivity were registered at ebbing, when the tide flushed city-polluted waters outward. Thermotolerant coliforms, $\mathrm{BOD}, \mathrm{PO}_{4}{ }^{3-}$ and N-products also presented statistically higher concentrations at the inner point, T2, closer to point sources of pollution (Table 1). Water quality improvement at $\mathrm{T} 1$ was possibly the result of water mixing between Tucundubu Creek and the Guamá River, suggesting that the latter may act as a natural barrier preventing or minimizing water crossing between the eastern margin of Belém and Combú Island. Further studies are recommended in order to develop a better understanding of how pollution spreads at the mixing zone before developing a new municipal sewage and waste water management strategy. Seasonal variations were observed with higher turbidity, DO, and N-products during the rainy season (Figure 2a). Rises in turbidity depending on the basin drainage area and water flow are commonly documented and related to sediment re-suspension in the water column (Costa et al., 2013). This process also causes water aeration and a consequent increase in DO. The high concentrations of nitrogen, and more especially nitrate, are within the range of those observed in other large Brazilian cities that suffer from contamination by domestic wastes, with occasional values above $10 \mathrm{mg}$ $\mathrm{L}^{-1}$ (e.g. Braga et al., 2000). Such was also the case for $\mathrm{PO}_{4}{ }^{3-}$ which, also presenting lower concentrations than in the study conducted by Braga et al. (2000), was considered too high for human use, fishing activities and aquatic life according to the norms established by the Brazilian Ministry of Environment (CONAMA 357/2005). Thermotolerant coliforms were very high and contributed to the classification of Tucundubu waters in class Group IV (CONAMA 357/2005), suitable only for navigation and harmony landscaping. Bacterial fecal pollution is one of the main causes of waterborne disease and mortality in developing countries (Sosa-Rodriguez, 2012). Such results should raise major concerns among governmental authorities as high bacterial concentrations were not only detected in the area of study but also in various locations scattered along the western margin of Belém City (Ribeiro, 2004) where children play in the water and fish with lines.

This study on Tucundubu Creek confirmed that water quality is the result of both the hydrological cycle and of anthropogenic activities in the watershed, with predictable seasonal variations related essentially to rain, and confined alterations of water properties through time and space due to human activities (Srivastava et al., 2011). On the contrary, results obtained in Combú Creek waters indicated no statistical differences between sampling sites or tides suggesting little contaminant input from riverines. Seasonal differences were observed, however, with higher concentrations of N-products, thermotolerant coliforms and suspended matter during the rainy season (Figure 2b). Nitrate, present in concentrations as high as those in Tucundubu Creek, suggested water deterioration within the preserved area. However, unlike Tucundubu Creek, which crosses city pavements and paved areas, Combú Creek is part of a wetland forest suggesting that its nutrients load was more likely a reflection of natural environmental conditions than a consequence of Belém's human activities. The contribution of non-point sources of pollution of nitrogen and phosphorus concentrations were largely debated by Howarth et al. (2000) as both parameters represent a major problem for the vital coastal waters of the United States. Thermotolerant coliforms, although much fewer than in 
Tucundubu Creek, did indicate bacterial pollution and a threat to human health. Even though their concentrations were usually not too high, they are responsible for water quality classification into Groups II or III (CONAMA 357/2005). Group II is suitable, among others, for human consumption after basic treatment, protection of aquatic communities and recreation while Group III can be used for human consumption after conventional or advanced treatment, recreational fisheries activities and irrigation. The deterioration of protected areas is observed worldwide and associated with poor environmental monitoring and understanding, which hampers the development of proper management policies (Leverington et al., 2010).

Table 1. Temporal mean and standard deviation followed by the median of water parameters at all sampling sites. $\mathrm{DO}=$ dissolved oxygen $\left(\mathrm{mg} \mathrm{L}^{-1}\right) ; \mathrm{BOD}=$ biological oxygen demand $\left(\mathrm{mg} \mathrm{L}^{-1}\right)$; $\mathrm{COD}=$ chemical oxygen demand $\left(\mathrm{mg} \mathrm{L}^{-1}\right)$; Cnd = conductivity $\left(\mu \mathrm{S} \mathrm{cm}{ }^{-1}\right)$; TDS = total dissolved solids $\left(\mathrm{mg} \mathrm{L}^{-1}\right) ; \mathrm{PO}_{4}{ }^{3-}=$ phosphorus $\left(\mathrm{mg} \mathrm{L}^{-1}\right) ; \mathrm{NH}_{4}{ }^{+}=$ammonium $\left(\mathrm{mg} \mathrm{L}^{-1}\right) ; \mathrm{NO}_{3}{ }^{-}\left(\mathrm{mg} \mathrm{L}^{-1}\right)=$ nitrate; $\mathrm{CTr}=$ thermotolerant fecal coliforms (most probable number MPN 100 $\mathrm{ml}^{-1}$ ).

\begin{tabular}{|c|c|c|c|c|c|c|c|c|}
\hline \multirow{2}{*}{ Parameters } & \multicolumn{8}{|c|}{ Sites } \\
\hline & $\mathrm{C} 1$ & Median & $\mathrm{C} 2$ & Median & $\mathrm{T} 1$ & Median & $\mathrm{T} 2$ & Median \\
\hline DO & $5.4 \pm 1.8$ & 6 & $5.4 \pm 1.8$ & 5.9 & $5.6 \pm 2.0$ & 5.8 & $5.2 \pm 1.8$ & 6.2 \\
\hline BOD & $6.2 \pm 2.7$ & 6.5 & $5.4 \pm 3.1$ & 4.5 & $5.6 \pm 4.0$ & 5.0 & $8.6 \pm 4.0$ & 7.0 \\
\hline COD & $22.3 \pm 11.3$ & 18.5 & $24.4 \pm 18.3$ & 20.0 & $23.8 \pm 16.9$ & 21.0 & $27.9 \pm 17.7$ & 38.0 \\
\hline Cnd & $28.4 \pm 9.9$ & 28.5 & $32.4 \pm 11.3$ & 30.5 & $96.9 \pm 112.7$ & 45.0 & $172.6 \pm 123.7$ & 226.0 \\
\hline TDS & $14.1 \pm 4.9$ & 14.5 & $16.2 \pm 5.6$ & 15.0 & $50.3 \pm 60.7$ & 22.0 & $87.1 \pm 64.4$ & 122.0 \\
\hline $\mathrm{PO}_{4}{ }^{3-}$ & $0.2 \pm 0.2$ & 0.1 & $0.24 \pm 0.2$ & 0.1 & $0.31 \pm 0.62$ & 0.1 & $0.4 \pm 0.7$ & 0.1 \\
\hline $\mathrm{NH}_{4}^{+}$ & $0.3 \pm 0.4$ & 0.1 & $0.1 \pm 0.1$ & 0.1 & $0.8 \pm 0.5$ & 0.1 & $3.0 \pm 3.1$ & 2.0 \\
\hline $\mathrm{NO}_{3}^{-}$ & $1.8 \pm 2.4$ & 0.8 & $4.5 \pm 9.9$ & 0.8 & $2.4 \pm 1.5$ & 1.6 & $3.8 \pm 5.6$ & 1.6 \\
\hline $\mathrm{CTr}$ & $3273 \pm 2646$ & 2734 & $2930 \pm 1914$ & 3255 & $641,021 \pm 1266$ & 14,800 & $1,249,507 \pm 1,773,882$ & 246,000 \\
\hline
\end{tabular}

\subsection{Fish larvae}

A total of 47 and 66 samples were collected in Tucundubu and Cumbú Creeks, respectively. Sampling effort difference was due to lower water levels in Tucundubu Creek at ebbing that made access to T2 difficult.

In Tucundubu Creek, sampling site $\mathrm{T} 1$ showed a total of 327 fish larvae, corresponding to a mean density of $25.100 \mathrm{~m}^{-3}$. No significant differences were registered between densities recorded during the $\mathrm{D} / \mathrm{W}\left(72.100 \mathrm{~m}^{-3}\right)$, wet $\left(5.100 \mathrm{~m}^{-3}\right)$ and dry $\left(23.100 \mathrm{~m}^{-3}\right)$ seasons. No larvae were encountered in W/D (Figure 3a). Site T2 accounted for a total of 51 larvae (7. 100 $\mathrm{m}^{-3}$ ), all sampled during the $\mathrm{D} / \mathrm{W}$ season $\left(21.100 \mathrm{~m}^{-3}\right)$. At both sampling sites, mean densities of larval fish were significantly greater during flood tides than during ebb tides.

A total of 1,803 fish larvae (mean of $89.100 \mathrm{~m}^{-3}$ ) was captured at $\mathrm{C} 1$; statistical differences in densities were observed only between the wet $\left(133.100 \mathrm{~m}^{-3}\right)$ and $\mathrm{D} / \mathrm{W}(54$. $100 \mathrm{~m}^{-3}$ ) seasons. At site C2, 2,344 larvae, corresponding to an overall density of $109.100 \mathrm{~m}^{-3}$, were captured. The dry season $\left(305.100 \mathrm{~m}^{-3}\right)$ presented densities statistically higher than during the other periods. The lower densities were registered in the W/D (mean of $34.100 \mathrm{~m}^{-3}$ ) (Figure 3a). There were no statistical differences between ebb and flood tide densities.

Larval fish communities were represented by the Orders Clupeiformes, Perciformes, Characiformes and Tetraodontiformes including six families: Clupeidae, Engraulidae, Pristigasteridae, Sciaenidae, Hemiodontidae and Tetraodontidae. In both creeks, Clupeiformes largely dominated, representing $98 \%$ of the catch. Clupeidae, Engraulidae, Pristigasteridae and Sciaenidae families were registered in Tucundubu Creek. Clupeids and engraulids 
represented $85 \%$ and $7 \%$, respectively, of the identified larvae. Clupeids prevailed at both points. In all seasons, more than half of captured larvae in Tucundubu Creek were in pre-flexion stage, including $4 \%$ of larvae with yolk-sacs that were found at both sites. The other stages of development showed a decrease of relative abundance from the pre-flexion to the post-flexion stages.

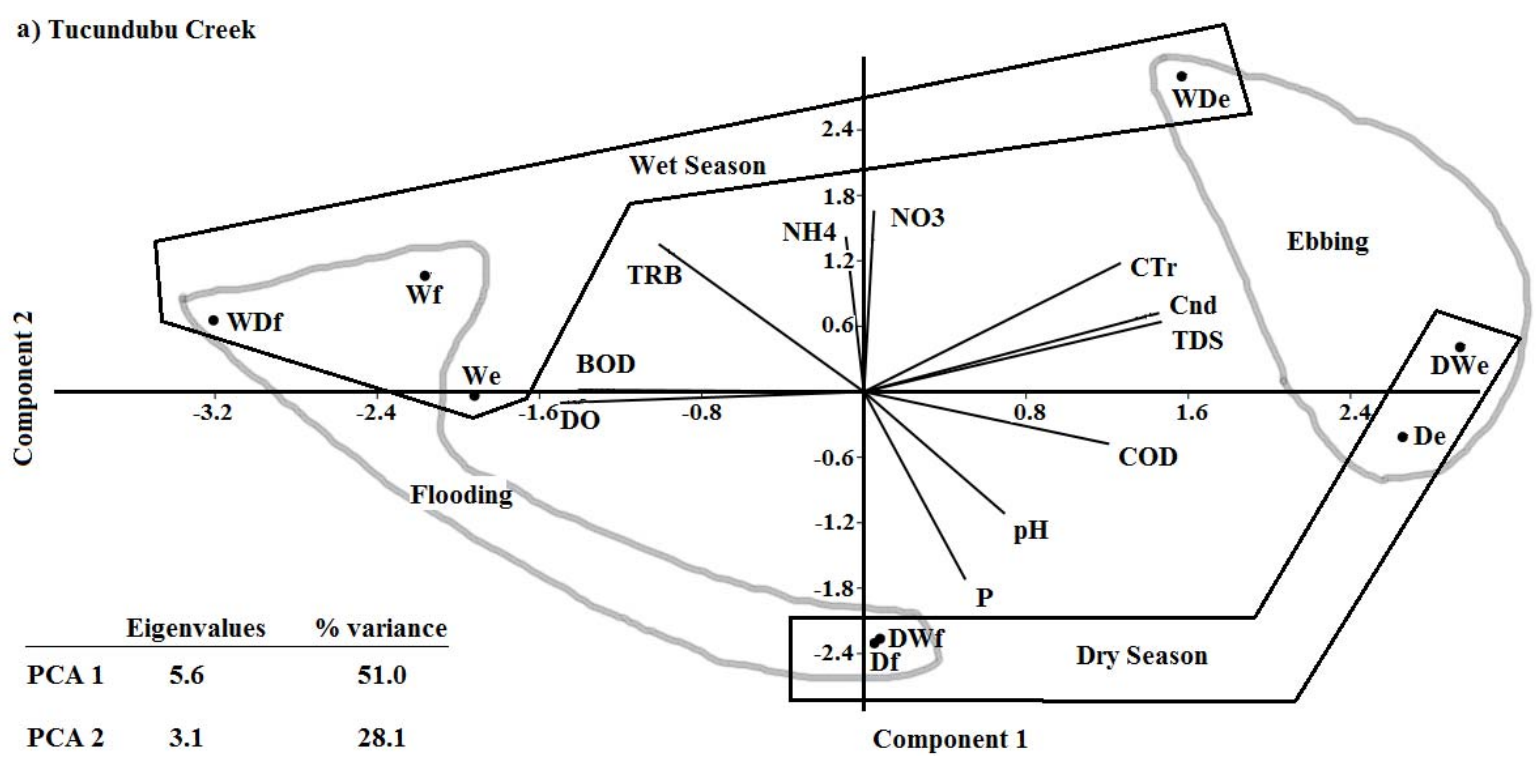

b) Combú Creek

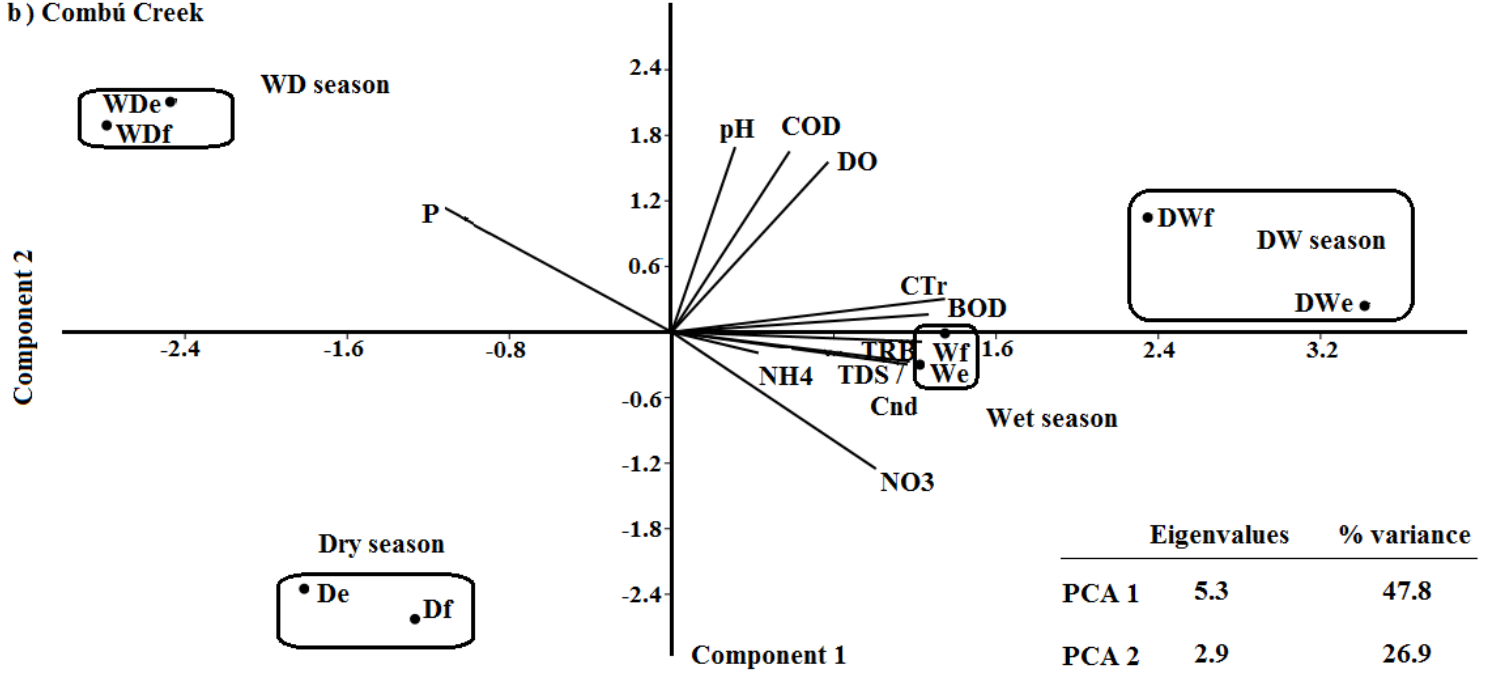

Figure 2. Principal Components Analysis applied on the environmental variables registered at Tucundubu (a) and Combú (b) creeks at all seasons and tides. Boxes represent possible case groupings. $\mathrm{DO}=$ dissolved oxygen $\left(\mathrm{mg} \mathrm{L}^{-1}\right)$; $\mathrm{BOD}=$ biological oxygen demand $\left(\mathrm{mg} \mathrm{L}^{-1}\right)$; $\mathrm{COD}=$ chemical oxygen demand $\left(\mathrm{mg} \mathrm{L}^{-1}\right) ; \mathrm{Cnd}=$ conductivity $\left(\mu \mathrm{Sm}^{-1}\right) ; \mathrm{TDS}=$ total dissolved solids $\left(\mathrm{mg} \mathrm{L}^{-1}\right) ; \mathrm{P}=$ phosphorus $\left(\mathrm{mg} \mathrm{L}^{-1}\right) ; \mathrm{NH}_{4}=\operatorname{ammonium}\left(\mathrm{mg} \mathrm{L}^{-1}\right) ; \mathrm{NO}_{3}\left(\mathrm{mg} \mathrm{L}^{-1}\right)$ $=$ nitrate; $\mathrm{CTr}=$ thermotolerant fecal coliforms (most probable number MPN $100 \mathrm{ml}^{-1}$ ); WD $=$ wet/dry season; $\mathrm{D}=$ Dry season; $\mathrm{D} / \mathrm{W}=$ dry $/$ wet; $\mathrm{W}=$ wet season, $\mathrm{f}=$ flood tide, $\mathrm{e}=\mathrm{ebb}$ tide. 
Combú Creek included all six families mentioned above. Hemiodontids and tetraodontids were captured only at $\mathrm{C} 2$ in the D/W transition period. Clupeiformes (Clupeidae, Engraulidae, Pristigasteridae families and non-identifies individuals) accounted for about $99 \%$ of the catch, with mainly clupeids. The other families were sporadic without relation to seasons or tides. All development stages were captured throughout the year with an overall prevalence of pre-flexion larvae (46\%), followed by larvae in flexion (38\%). The only exceptions were registered at $\mathrm{C} 1$ and $\mathrm{C} 2$ in the wet and dry season respectively, when flexion larvae were more abundant.

a)

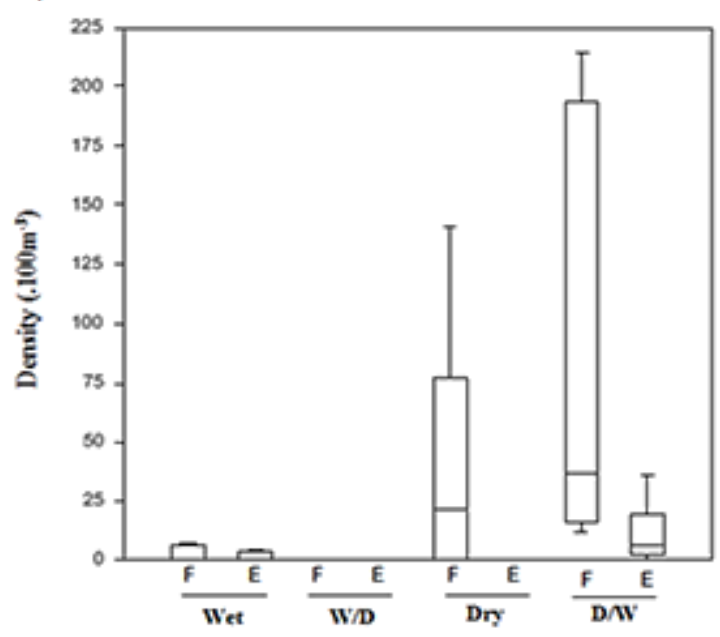

b)

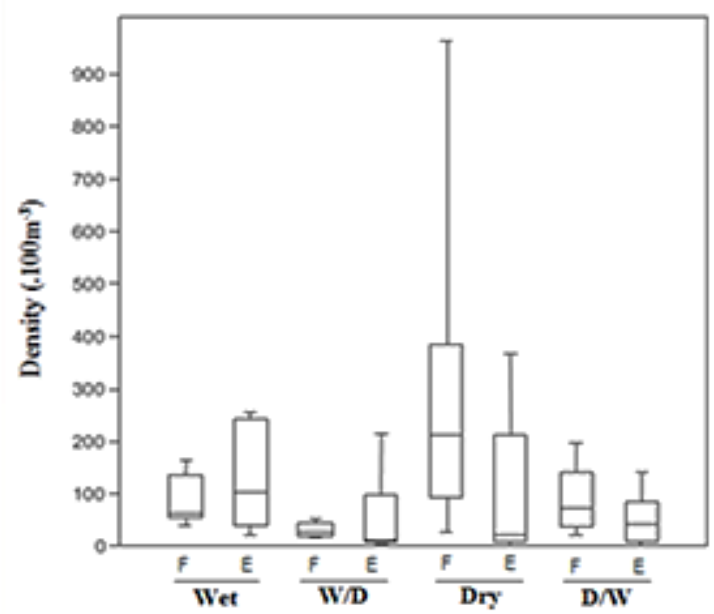

Figure 3. Box plots based upon larval densities at Tucundubu (a) and Combú bB) Creeks during the four seasonal periods, differentiating the ebb (E) and (F) flood tides. $\mathrm{W}=$ wet, $\mathrm{W} / \mathrm{D}=$ wet $/$ dry, $\mathrm{D}=$ Dry, $\mathrm{D} / \mathrm{W}=$ dry/wet seasons. Note that the scale differs between graphs.

BIOENV results showed that the environmental variables that best explained distribution patterns of fish larvae were thermotolerant coliforms $(-0.98)$ in Tucundubu Creek and $\mathrm{NO}_{3}{ }^{-}$in Combú Creek (0.48).

Differences in densities and, to a lower extent, diversity between both creeks pointed to unsuitable conditions for larval survival in Tucundubu Creek. The absence of open natural areas that could be used as nursery grounds as it is the case in Combú Creek could explain this result. However, water quality deterioration in Tucundubu Creek is most likely responsible for the changes in fish larvae densities, as reported in other impacted water courses (Konig et al., 2008) and sustained by BIOENV analysis result. The higher quantity of larvae registered at flooding and T1 indicated that individuals entered from the Guamá River into Tucundubu Creek, but that few larvae survived within the creek, unlike in Combú Creek where no differences were observed between tides and sites. It is noted that although Combú Creek presented higher density and diversity, both parameters remained low when compared to fish larvae communities encountered in the Amazonian Basin (Costa et al., 2011) or closer to the coast (Barletta-Bergan et al., 2002). This pattern is usually associated with all oligohaline areas that benefit few species but represent important nursery grounds (Sarpedonti et al., 2013). Clupeiformes' dominance has been documented in many Brazilian estuaries and worldwide, and associated with their extensive physiological plasticity.

The larval peak in density observed during the dry season agrees with the match-mismatch hypothesis that associates fish hatching with food availability (Cushing, 1990) that, in Belém, increases at the end of the dry season (Paiva et al., 2006). The importance of nutrients for the young's survival was sustained by BIOENV analysis result that indicated nitrates as the principal water parameter associated (positively) to larval 
communities in Combú Creek.

Fish larvae are considered good bio indicators for short-term quality changes in response to anthropogenic pressures (Ramos et al., 2015). In the study area, densities did reflect water quality with very few individuals in Tucundubu Creek. However, diversity was not considered appropriate for environmental impact assessments due to the naturally low number of fish species using the locale as a nursery ground.

\section{CONCLUSION}

This study found a drastic deterioration in the water quality of Tucundubu Creek associated essentially with extremely high levels of fecal coliforms and peaks of nutrients that rendered the environment unsuitable for human use and aquatic life. The results suggest an urgent need for authorities to develop new urban management plans in order to improve health and sanitation conditions. The protected area of Combú Island showed signs of contamination, although part of it was probably the result of non-point source pollution. A close follow-up study of the site is suggested, including hydrodynamic surveys, in order to determine the effect of Belem's mainland anthropogenic activities on the protected area. Fish larvae densities were considered suitable bio indicators for environmental impact assessments in the area, unlike the biodiversity index, which was determined to be unsuitable due to the naturally low number of taxa.

\section{ACKNOWLEDGMENTS}

The authors thank the Bureau of Environment (DEMA) staff and all laboratory colleagues for their assistance during field campaigns, the National Council for Scientific and Technologic Development (CNPq) for their financial support (Project N. 481157/2010-7) and the Institutional program for Graduates' Scholarship from Federal University of Pará (PIBIC / UFPA).

\section{REFERENCES}

BARLETTA-BERGAN, A.; BALETTA, M.; SAINT-PAUL, U. Structure and seasonal dynamics of larval fish in the Caete River Estuary in North Brazil. Estuarine, Coastal and Shelf Science, v. 54, p. 193-206, 2002. http://dx.doi.org/10.1006/ecss.2001.0842

BRAGA, E. S.; BONETTI, C. V. D. H.; BURONE, L.; BONETTI FILHO, J. Eutrophication and bacterial pollution caused by industrial and domestic wastes at the Baixada Santista Estuarine System, Brazil. Marine Pollution Bulletin, v. 40, n. 2, p. 165-173, 2000. http://dx.doi.org/10.1016/S0025-326X(99)00199-X

COSTA DA, A. J. G.; COSTA DA, K. G.; PEREIRA, L. C. C.; SAMPAIO, M. I.; COSTA DA, R. M. Dynamics of hydrological variables and the fish larva community in an Amazonian estuary of northern Brazil. Journal of Coastal Research, v. 64, p. 19601964, 2011.

COSTA DA, A. K. R.; PEREIRA, L. C. C.; da COSTA, R. M.; MONTEIRO, M. C.; de JESUS FLORES-MONTES, M. Oceanographic processes in an Amazon estuary during an atypical rainy season. Journal of Coastal Research, v. 65, p. 1104-1109, 2013.

CUSHING, D. H. Plankton production and year-class strength in fish populations: an update of the match/mismatch hypothesis. Advances in Marine Biology, v. 26, p. 249-293, 1990. 
FRIENDLY, A. The right to the city: theory and practice in Brazil. Planning Theory \& Practice, v. 14, n. 2, p. 158-179, 2013.

http://dx.doi.org/10.1080/14649357.2013.783098

HAMMER, Ø; HARPER, D. A. T.; RYAN, P. D. PAST: Paleontological statistics software package for education and data analysis. Paleontologia Electronica, v. 4, n. 1, p. 1-9, 2001 .

HOWARTH, R.; ANDERSON, D.; CLOERN, J.; ELFRING, C.; HOPKINSON, C.; LAPOINTE, B. et al. Nutrient pollution of coastal rivers, bays and seas. Issues in Ecology, v. 7, 2000.

KONIG, R.; SUZIN, C. H.; RESTELLO, R. M.; HEPP, L. U. Qualidade das águas de riachos da região norte do Rio Grande do Sul (Brasil) através de variáveis físicas, químicas e biológicas. Pan-American Journal of Aquatic Sciences, v. 3, n. 1, p. 84-89, 2008.

LEVERINGTON, F.; COSTA, K. L.; PAVESE, H.; LISLE, A.; HOCKINGS. A global analysis of protected area management effectiveness. Environmental Management, v. 46, n. 5, p. 685-698, 2010. http://dx.doi.org/10.1007/s00267-010-9564-5

NAKATANI, K.; AGOSTINHO, A. A.; BAUMGARTNER, G.; BIALETZKI, A.; SANCHES, P. V.; CAVICCHIOLI, M. et al. Ovos e larvas de peixes de água doce: desenvolvimento e manual de identificação. Maringá: UEM/Nupélia, 2001. 359 p.

PAIVA, R. S.; ESKINAZI-LEÇA, E.; PASSAVANTE, J. Z. O.; SILVA-CUNHA, M. G. G.; MELO, N. F. A. C. Considerações ecológicas sobre o fitoplâncton da Baía de Guajará e Foz do Rio Guamá (Pará, Brasil). Boletim do Museu Paraense Emílio Goeldi, v. 1, n. 2, p. 133-146, 2006.

PEPTENATU, D.; PINTILII, R. D.; DRAGHICI, C. Environmental risk management of urban growth poles regarding national importance. International Journal of Environmental Sciences and Technology, v. 8, n. 4, p. 737-746. 2011.

RAMOS, S.; CABRAL, H.; HELLIOTT, M. Do fish larvae have advantages over adults and other components for assessing estuarine ecological quality? Ecological Indicators, v. 55, p. 74-85, 2015. http://dx.doi.org/10.1016/j.ecolind.2015.03.005

RIBEIRO, K. T. S. A água e saúde humana em Belém. Belém: Cejup. 2004. 280 p. (Megan, 2)

SARPEDONTI, V.; ANUNCIAÇÃO, M. A.; BORDALO, A. Spatio-temporal distribution of fish larvae in relation to ontogeny and water quality in the oligohaline zone of a North Brazilian estuary. Bioto Neotropica, v. 13. n. 3, p. 55-63, 2013. http://dx.doi.org/10.1590/S1676-06032013000300007

SOSA-RODRIGUEZ, F. S. Assessing water quality in the developing world: an index for Mexico City. In: VOUDOURIS, K.; VOUTSA, D. (Eds.). Water quality monitoring and assessment. [S.1.]: InTech, 2012. p. 495-508. http://dx.doi.org/10.5772/32055

SRIVASTAVA, S.; SRIVASTAVA, A, S.; NEGI M. P. S.; TANDON, P. K. Evaluation of effect of drains on water quality of river Gomti in Lucknow city using multivariate statistical techniques. International Journal of Environmental Sciences, v. 2, n. 1, p. $1-7,2011$. 
WORLD WIDE FOUND FOR NATURE - WWF. World Water Assessment Programme. Water: a shared responsibility. Paris: UNESCO, 2006. p. 43. 